\title{
Anti-inflammatory and anti-Helicobacter effects of the Aralia elata hot-water extract
}

\author{
Se-Won Lee ${ }^{1}$, Jeong Ho Lee ${ }^{2 *}$ \\ ${ }^{1}$ Division of Biotechnology, Jeonbuk National University, Iksan 54596, Korea \\ ${ }^{2}$ Sunchang Research Institute of Health and Longevity, Sunchang 56015, Korea
}

\section{두릅 열수추출물의 항염 및 항헬리코박터 효과 \\ 이세 원 ${ }^{1} \cdot$ 이정호 $^{2 *}$ \\ ${ }^{1}$ 전북대학교 생명공학부, ${ }^{2}$ (재)순창건강장수연구소}

\begin{abstract}
Aralia elata contains several bioactive compounds, such as saponin, oleanolic acid, and beta-carotene, which are known widely to control blood pressure and diabetes. In this study, we investigated the anti-Helicobacter pylori, antioxidant, anti-inflammatory, and cytotoxic effects of the extract of $A$. elata which was procured from Sunchang-gun, South Korea. The extract was prepared using water bath at $80^{\circ} \mathrm{C}$ for $5 \mathrm{~h}$. The total polyphenolics content in $A$. elata hot-water extract was $186.8 \pm 2.7 \mathrm{mgGAE} / \mathrm{g}$, and the total flavonoid content was $81.9 \pm 1.5 \mathrm{mgQE} / \mathrm{g}$. In addition, the extract exhibited anti-Helicobacter pylori activity and the growth of the bacteria was decreased with increasing concentration of the extract. $\mathrm{SC}_{50}$ value of DPPH radical scavenging activity was $3,274.7 \pm 47.7 \mu \mathrm{g} / \mathrm{mL}$, and ABTS radical scavenging activity was $2,660.1 \pm 50.3 \mu \mathrm{g} / \mathrm{mL}$. Furthermore, $A$. elata hot-water extract reduced the production of nitric oxide (NO), TNF- $\alpha$, IL-1 $\beta$, and IL-6 in LPS-stimulated RAW264.7 cells. Cell viability assay revealed no cytotoxicity in RAW264.7 cells even at a concentration of $100 \mu \mathrm{g} / \mathrm{mL}$. The results confirmed that $A$. elata hot-water extract could be used as an antioxidant, antibacterial, and anti-inflammatory agent.
\end{abstract}

Key words : Aralia elata, Helicobacter pylori, antimicrobial activity, anti-inflammatory effect, pro-inflammatory cytokine

서 론

염증반응은 기본적인 면역반응으로 인체 내 대부분 기관 에서 유발된다(Chae 등, 2011). 염증반응은 물리·화학적 자 극이나 세균감염과 같은 외부 유해물질에 대응하기 위한 생 체의 방어기작이며, 손상된 조직이나 장기를 회복시키는 역 할을 한다(Lee 등, 2017). 대식세포(macrophage)는 동물 체 내 모든 조직에 존재하며, 면역기능과 항상성 유지를 담당하 는 세포로 유해물질, 바이러스, 세균 및 노화 세포 등을 외부 로 배출시키는 역할을 하고, 염증 유발 물질이 유입되면 염증
매개 물질을 분비하여 신체를 보호하고 기능을 유지할 수 있 게 한다(Kim 등, 2018; Min과 Park, 2009). 그러나 지속적인 염증반응으로 인하여 대식세포가 과도하게 반응하면 염증 매 개 물질이 과발현되어 종양, 자가면역질환 및 제 2 형 당뇨 등 다양한 질병을 일으키는 요인이 된다(Hofseth와 Ying, 2006). 염증반응은 lipopolysaccharide(LPS), 활성산소종, 사이토카 인 등을 통해 염증반응이 활성화되어 nitric oxide(NO) 및 prostaglandin $\mathrm{E}_{2}$ 등의 염증인자나 tumor necrosis factor- $\alpha$ (TNF- $\alpha$ ), interleukin-1 $\beta(\mathrm{IL}-1 \beta)$, interleukin-6(IL-6)과 같은 염증성 사이토카인의 생성에 관여한다(Kim 등, 2019). NO는

*Corresponding author. E-mail : wooju1119@naver.com, Phone : +82-63-653-8708, Fax : +82-63-653-8710

Received 02 November 2020; Revised 22 December 2020; Accepted 22 December 2020.

Copyright (c) The Korean Society of Food Preservation.

This is an Open Access article distributed under the terms of the Creative Commons Attribution Non-Commercial License (http://creativecommons.org/licenses/by-nc/4.0) which permits unrestricted non-commercial use, distribution, and reproduction in any medium, provided the original work is properly cited. 
reactive nitrogen species(RNS)의 일종이며, $\mathrm{O}_{2}$ 과 반응하여 peroxynitrite를 생성한다(Lee와 Jeong, 2006). Peroxynitrite 는 산화제로 작용하여 지질과 단백질의 과산화를 유도시키 고, 세포독성을 일으킨다(Radi 등, 1991). 따라서 염증반응 억제는 염증질환을 치료하는 데 있어 중요한 목표가 된다.

최근 우리나라의 주요 암종별 유병률은 갑상선암 $21.7 \%$, 위 암 $15.5 \%$, 대장암 $13.4 \%$, 유방암 $11.6 \%$ 이며(Healthcare Bigdata Hub, 2018), 이 중 위암의 유병률이 높은 것은 우리 나라 사람들의 서구화된 식생활 환경 등 다양한 요인이 존재 하지만 Helicobacter pylori(H. pylori)와 같은 위염 원인균의 감염도 중요한 요인 중 하나이다(Park과 Kim, 2006). 만성 위 염, 위궤양, 소화불량 등 소화기 질환을 일으키는 인자로 알려 진 H. pylori의 국내 감염률은 $51 \%$ 이다(Ahn, 2019). H. pylori 는 일반적으로 프로톤 펌프 억제제(proton pump inhibitor)를 기초로 하여 아목시실린(amoxicillin), 클라리트로마이신(clarithromycin) 또는 레보플록사신(levofloxacin)로 치료하는 것으로 알려져 있다(Choi 등, 2018). 그러나 삼제요법의 치료는 질병 의 재발, 내성균주의 출현 및 환자의 약제 부적응 등 여러 문 제를 발생시킨다(Francesco 등, 2011). 이에 따라 최근에는 로즈마리(Yoon 등, 2011), 돌나물(Choi 등, 2012), 강황(Oh 등, 2020), 소함흉탕 및 황련(Lee 등, 2014) 등 천연소재를 활용한 H. pylori에 대한 항균활성 연구가 증가하고 있다.

두릅(Aralia elata)은 두릅나무과(Araliaceae)에 속하는 식 물로 크기는 4-5 m 정도이며, 봄철에는 새순을 식용으로 섭 취하고, 뿌리는 약용으로 사용한다(Moon 등, 1999). 두릅에 는 사포닌, 올리에놀산, 트라이터펜, 베타 카로텐, 아스코르브 산 등의 성분이 함유되어 있는 것으로 알려져 있으며(Kwon 등, 2018), 항산화 효과(Cha 등, 2009), 항고혈압 효과(Jin 등, 2017), 당뇨예방 효과(Kim 등, 2004) 등이 보고된 바 있다. 이 외에도 항염증(Lee 등, 2009), 살모넬라와 대장균의 생장 억제(Ma 등, 1996) 등에 대한 연구가 보고되어 있지만, $H$. pylori의 항균효과에 관한 보고는 찾아보기 힘든 실정이다.

이에, 본 연구에서는 두릅을 이용하여 H. pylori의 항균활 성을 확인하고, 염증발생에 대한 억제능은 대식세포를 이용 하여 NO, TNF- $\alpha, \mathrm{IL}-1 \beta$ 및 IL-6 평가를 통해 조사하였다.

\section{재료 및 방법}

\section{실험재료}

2020년 5월 전북 순창군 농특산물 직판장에서 구매한 두 릅(Aralia elata)은 수돗물로 수세하여 이물질을 제거하고, 2 $\mathrm{mm}$ 두께로 자른 후 건조기를 이용하여 $60^{\circ} \mathrm{C}$ 에서 건조하였 다. 건조한 두릅은 20 mesh에 통과할 정도로 분쇄기(Philips, HR3752/00, Amsterdam, Nederland)로 분쇄하였으며, 얻어
진 분말은 $4^{\circ} \mathrm{C}$ 에서 저온 저장하며 실험에 사용하였다. 본 연 구에서 항산화 성분 분석, 항균활성 및 항염증 활성 측정에 사 용된 시약은 1-diphenyl-2-picrylhydrazyl(DPPH), 2,2'-azinobis(3-ethylbenzothiazoline-6-sulfonic acid) diammonium salt (ABTS), ascorbic acid, Folin-Ciocalteu's phenol reagent, gallic acid, quercetin, potassium persulfate $\left(\mathrm{K}_{2} \mathrm{~S}_{2} \mathrm{O}_{8}\right)$, amoxicillin, lipopolysaccharide(LPS), 3-(4,5-dimethylthiazol-2-yl)-2,5diphenyltetrazolium bromide(MTT)은 Sigma-Aldrich Chemical Co.(St. Louis, MO, USA)에서 구입하였다. Dulbecco's Modified Eagle Medium(DMEM), fetal bovine serum(FBS), penicillin-streptomycin(PS)은 HyClone(Pittsburgh, PA, USA) 에서 구입하여 사용하였다.

\section{두릅 추출물의 제조}

건조된 두릅을 증류수로 $80^{\circ} \mathrm{C}$ 의 water bath에서 5 시간 동 안 추출하였다. 추출액은 원심분리기 $(3,000 \times g)$ 에서 10 분간 원 심분리하고, 여과지(Advantec No.2, Toyo Roshi Co., Ltd., Tokyo, Japan)를 사용하여 여과하였다. 여과한 추출액은 freezer (CLN-50C, Nihon freezer Co., Ltd., Tokyo, Japan)를 사용하 여 동결한 다음 동결건조기(FD 8508, IlShin BioBase Co., Ltd., Dongducheon, Korea)를 사용하여 $-80^{\circ} \mathrm{C}$ 에서 동결건조 하였다. 건조된 시료(수율 $12.8 \%$ )는 증류수에 완전히 용해하 여 시료액으로 사용하였다.

\section{항산화성분 함량 측정}

두릅 열수추출물의 총폴리페놀 함량은 Folin-Denis법 (Singleton과 Rossi, 1965)으로 측정하였다. 농도별로 조제한 두릅 열수추출물 $1 \mathrm{~mL}$ 에 $1 \mathrm{~N}$ Folin-Ciocalteu's reagent 0.5 $\mathrm{mL}$ 를 첨가하여 혼합한 다음, $5 \% \mathrm{Na}_{2} \mathrm{CO}_{3} 1 \mathrm{~mL}$ 를 첨가하여 암소에서 1 시간 동안 반응시킨 후 분광광도계(Agilent 8453 , Agilent, Santa Clara, CA, USA)를 이용하여 $725 \mathrm{~nm}$ 에서 흡광 도를 분석하였다. 두릅에 함유된 총폴리페놀 함량은 gallic acid의 표준곡선 $(25-200 \mu \mathrm{L} / \mathrm{mL})$ 을 이용하여 측정하였고, 회귀 식은 $\mathrm{y}=0.0055 \mathrm{x}-0.0318\left(\mathrm{R}^{2}=0.9969\right)$ 로 나타났으며, 총폴리페 놀 함량은 $\mathrm{mg}$ gallic acid equivalent $(\mathrm{GAE}) / \mathrm{g}$ 으로 나타내었다.

두릅 열수추출물의 총플라보노이드 함량은 Moreno 등 (2000)의 방법을 응용하여 측정하였다. 두릅 열수추출물 0.5 $\mathrm{mL}$ 에 $10 \%$ aluminum nitrate $0.1 \mathrm{~mL}$ 와 $1 \mathrm{M}$ potassium acetate $0.1 \mathrm{~mL}$ 를 순차적으로 첨가한 후, ethanol $4.3 \mathrm{~mL}$ 를 가하여 혼합하고, 40 분간 실온에서 반응시킨 다음 $415 \mathrm{~nm}$ 에 서 흡광도를 측정하였다. 총플라보노이드 함량은 quercetin의 표준곡선 $(20-100 \mu \mathrm{L} / \mathrm{mL})$ 을 이용하여 측정하였고, 회귀식은 $\mathrm{y}=0.0014 \mathrm{x}+0.0011\left(\mathrm{R}^{2}=0.9989\right)$ 로 나타났으며, 총플라보노이 드 함량은 $\mathrm{mg}$ quercetin $(\mathrm{QE}) / \mathrm{g}$ 으로 나타내었다. 


\section{항산화 활성 측정}

두릅 열수추출물의 DPPH 라디칼 소거활성은 Blois (1958)법으로 측정하였다. 여러 농도로 조정된 시료 $40 \mu \mathrm{L}$ 와 메탄올로 제조된 $0.2 \mathrm{mM} \mathrm{DPPH}$ 용액 $180 \mu \mathrm{L}$ 를 96-well plate에 혼합하고 $37^{\circ} \mathrm{C}$ 에서 30 분간 반응시켰다. Microplate reader(Infinite M200 Pro, Tecan Group Ltd., Zurich, Switzerland)를 사용하여 $517 \mathrm{~nm}$ 에서 흡광도를 측정하였다. $\mathrm{DPPH}$ 라디칼 소거활성은 아래 식에 대입하여 산출하였으며, 라디칼 소거활성(\%) 값을 $50 \%$ 감소시키는 scavenging concentration $(\mathrm{SC})_{50}$ 값으로 표시하였으며, 대조군은 ascorbic acid을 사용하였다.

$\mathrm{DPPH}$ 라디칼 소거활성 $(\%)=$

$$
1-\frac{\text { 시료 첨가군의 흡광도 }}{\text { 시료 무첨가군의 흡광도 }} \times 100
$$

두릅 열수추출물의 ABTS 라디칼 소거활성은 Van den Berg 등(1999)의 방법을 일부 변형하여 측정하였다. 증류수 로 제조한 $7 \mathrm{mM}$ ABTS 용액에 $2.4 \mathrm{mM}$ 의 potassium persulfate를 첨가한 다음 12 시간 동안 반응시키고, $734 \mathrm{~nm}$ 에 서 흡광도 1.0 이 되도록 증류수로 조정하였다. 농도별로 조제 된 두릅 열수추출물 $10 \mu \mathrm{L}$ 와 ABTS 용액 $190 \mu \mathrm{L}$ 를 96-well plate에 혼합하고 10 분간 상온에서 반응시킨 다음 microplate reader를 사용하여 $734 \mathrm{~nm}$ 에서 흡광도를 측정하였다. 두릅 열수추출물의 $\mathrm{ABTS}$ 라디칼 소거활성은 아래 식에 대입하여 산출하였으며, 라디칼 소거활성(\%) 값을 $50 \%$ 감소시키는 $\mathrm{SC}_{50}$ 값으로 표시하였으며, 대조군은 ascorbic acid을 사용하 였다.

$\mathrm{ABTS}$ 라디칼 소거활성 $(\%)=$

$$
1-\frac{\text { 시료 첨가군의 흡광도 }}{\text { 시료 무첨가군의 흡광도 }} \times 100
$$

\section{항균활성 측정}

Helicobacter pylori(H. pylori) 균주는 경상대학교 의학전 문대학원 헬리코박터 균주은행으로부터 분양받아 실험에 사 용하였다. 균주배양은 $10 \% \mathrm{FBS}$ 가 첨가된 brucella agar 배지 에 균주를 접종하고, $37^{\circ} \mathrm{C}, 10 \% \mathrm{CO}_{2}$ 배양기에서 배양하였다.

두릅 열수추출물의 항균 활성은 paper disc diffusion method를 이용하여 측정하였다. 농도별로 제조된 두릅 열수 추출물을 paper disc에 $100 \mu \mathrm{L}$ 씩 주입하고 30 분간 건조한 다 음, H. pylori가 도말된 brucella agar 배지에 삽입한 후 $37^{\circ} \mathrm{C}$,
$10 \% \mathrm{CO}_{2}$ 배양기에서 24시간 배양하였다. 이후 두릅 열수추 출물에 의해 생성된 clear zone을 측정하였으며, 대조군은 amoxicillin을 사용하여 두릅 열수추출물과 항균 활성을 비교 하였다.

\section{최소저해농도(MIC)와 최소사멸농도(MBC)의 결정}

두릅 열수추출물의 $H$. pylori에 대한 최소저해농도 (minimal inhibitory concentration)는 broth-microdilution method(Takarada 등, 2004)를 이용하여 측정하였다. 96-well plate에 brucella broth 배지를 $100 \mu \mathrm{L}$ 씩 분주하고, 농도별 두 릅 추출물을 $50 \mu \mathrm{L}$ 분주한 다음 $\mathrm{OD}_{600} 0.2$ 로 조절한 균주액 을 $50 \mu \mathrm{L}\left(0.5 \times 10^{7} \mathrm{CFU} / \mathrm{mL}\right)$ 첨가하여 24 시간 동안 $37^{\circ} \mathrm{C}$ 의 $10 \% \mathrm{CO}_{2}$ 배양기에서 배양하였다. 이후 microplate reader를 이용해 $600 \mathrm{~nm}$ 에서 균주의 생장을 확인할 수 없는 농도를 $\mathrm{MIC}$ 로 하였다. 균이 생장하지 않은 혼합액을 brucella agar 배지에 도말하여 $37^{\circ} \mathrm{C}$ 에서 24 시간 배양한 뒤, colony가 확인 되지 않은 최소농도를 최소사멸농도(minimal bactericidal concentration)로 결정하였다.

\section{세포배양 및 세포생존율 측정}

RAW264.7 대식세포는 한국세포주은행(KCLB, Seoul, Korea)에서 분양 받아 $10 \%$ fetal bovine serum, 100 unit $/ \mathrm{mL}$ 의 penicillin-streptomycin이 첨가된 Dulbecco's Modified Eagle Medium 배지를 사용하여 $37^{\circ} \mathrm{C}, 5 \% \mathrm{CO}_{2}$ 배양기에서 배양하였다.

두릅 열수추출물의 처리에 따른 RAW264.7 대식세포의 생존율 측정은 Chamichael 등(1987)의 방법을 이용하여 측 정하였다. 세포를 96-well plate에 $1 \times 10^{5}$ cell/well로 분주하 고, 24시간 동안 배양한 후 농도별로 희석된 두릅 추출물을 $100 \mu \mathrm{L}$ 첨가한 후 $37^{\circ} \mathrm{C}$ 의 $5 \% \mathrm{CO}_{2}$ 배양기에서 24 시간 배양 하였다. 배양한 후 $0.5 \mathrm{mg} / \mathrm{mL}$ 의 MTT 용액을 well에 $50 \mu \mathrm{L}$ 첨가하고 4시간 동안 반응시킨 다음 용액을 제거하고 실온에 서 건조하였다. 이후 DMSO $200 \mu \mathrm{L}$ 를 첨가하여 각 well에 생성된 formazan 결정을 완전히 용해하고 microplate reader 로 $540 \mathrm{~nm}$ 에서 흡광도를 측정하였다.

\section{Nitric oxide(NO) 생성억제능 측정}

두릅 열수추출물의 NO 생성억제능은 Green 등(1982)의 방법을 이용하여 측정하였다. RAW264.7 세포를 24-well plate에 $5 \times 10^{5} \mathrm{cell} / \mathrm{well}$ 로 분주하고 24 시간 배양한 후, 농도 별로 제조한 두릅 시료를 세포에 2시간 처리한 다음 LPS 1 $\mu \mathrm{g} / \mathrm{mL}$ 를 첨가하여 24시간 염증반응을 유도하였다. 이후 세 포배양 상등액 $100 \mu \mathrm{L}$ 와 griess 시약 $(0.1 \% \mathrm{~N}$-(1-naphtyl) ethylenediamine과 $1 \%$ sulfanilamide $1: 1) 100 \mu \mathrm{L}$ 를 새로운 
96-well plate에 혼합하여 10 분간 반응시킨 후 microplate reader를 이용하여 $570 \mathrm{~nm}$ 에서 흡광도를 측정하였다.

\section{염증성 cytokine(TNF- $\alpha, \mathrm{IL}-1 \beta, \mathrm{IL}-6)$ 분비량 측정}

RAW264.7 세포를 24-well plate에 $5 \times 10^{5}$ cell/well이 되도 록 분주하고, 24 시간 동안 $37^{\circ} \mathrm{C}, 5 \% \mathrm{CO}_{2}$ 배양기에서 배양하 였다. 농도별로 제조한 두릅 열수추출물을 세포에 2시간 처 리한 다음, 각 well에 LPS $1 \mu \mathrm{g} / \mathrm{mL}$ 를 처리하고 24시간 배양 하였다. 이후 배양 상층액을 수거하여 실험에 사용하고, ELISA kit(ELISA MAXTM Deluxe Set, BioLegend, San Diego, CA, USA)를 이용하여 TNF- $\alpha$, IL-1 $\beta$, IL-6의 분비량 을 측정하였다. 실험방법은 manufacturer's instruction을 따 라 측정하였다.

\section{통계처리}

모든 실험의 통계처리는 통계 패키지인 Sigma plot(Sigma plot for window version 10.0, Microsoft Inc., Chicago, IL, USA) program을 이용하여 각 측정 군의 평균 \pm 표준편차를 산 출하였으며, t-test를 사용하여 유의성을 $\mathrm{p}<0.001, \mathrm{p}<0.005$, $\mathrm{p}<0.01$ 수준에서 검증하였다.

\section{결과 및 고찰}

\section{총폴리페놀 함량 및 총플라보노이드 함량}

식물계에 널리 분포되어 있는 식물성 polyphenol은 식물세 포의 생성과 활성화에 영향을 주는 것으로 알려져 있다(Kim, 2009). 또한, 식물이 자외선 또는 병원성 미생물의 침입을 방 어하기 위해 방출하는 물질로서 phenylalanine과 tyrosine으 로부터 합성되며, 항산화, 항암, 항염증, 항균 등의 효능을 갖 고 있다(Kim 등, 2018). 총폴리페놀 함량은 폴리페놀 산화. 환원반응을 응용한 것으로 phosphomolybdic acid와 반응하 여 청색으로 발색되는 원리를 이용하였다(Singleton과 Rossi, 1965).

두릅 열수추출물의 총폴리페놀 함량과 총플라보노이드 함 량을 측정하여 Table 1에 나타내었다. 두릅을 $80^{\circ} \mathrm{C}$ 에서 물로 추출하였을 때, 총폴리페놀 함량은 $186.8 \pm 2.7 \mathrm{mgGAE} / \mathrm{g}$ 으로 나타났다. 두릅 열수추출물의 총폴리페놀 함량을 다른 식용 및 약용 식물 추출물과 비교하면, 아로니아 $70 \%$ 에탄올 추출 물의 $117.2 \mathrm{mgGAE} / \mathrm{g}$ (Chung, 2014)보다는 높고, 돌단풀 물 추출물의 $183.8 \mathrm{mgGAE} / \mathrm{g}$ (Lee 등, 2011)과 비슷하였으며, 복 분자 잎 물추출물의 $190.7 \mathrm{mgGAE} / \mathrm{g}$ (Lee 등, 2014)보다는 낮게 나타났다. 플라보노이드는 폴리페놀에 속하는 성분으로 활성 산소종을 효과적으로 제거하여 항산화능이 높다고 알려 져 있으며, 폴리페놀과 마찬가지로 항암, 항염증 및 항바이러
Table 1. Total polyphenolics and flavonoid contents of $A$. elata hot-water extract

\begin{tabular}{lc}
\hline $\begin{array}{c}\text { Total polyphenolics } \\
(\mathrm{mg} \mathrm{GAE} / \mathrm{g})\end{array}$ & $\begin{array}{c}\text { Total flavonoid } \\
(\mathrm{mg} \mathrm{QE} / \mathrm{g})\end{array}$ \\
\hline $186.8 \pm 2.7^{3)}$ & $81.9 \pm 1.5$ \\
\hline${ }^{1)}$ Gallic acid equivalent. & \\
${ }^{3)}$ Quercetin equivalent. \\
${ }^{3)}$ alues represent the mean $\pm \mathrm{SD}(\mathrm{n}=3)$.
\end{tabular}

스 효과가 있는 것으로 알려져 있다(Kim 등, 2012). 두릅 열 수추출물의 총플라보노이드 함량은 $81.9 \pm 1.5 \mathrm{mgQE} / \mathrm{g}$ 으로 나타내었다. 항산화능이 높다고 알려진 한방 식물류인 감초 및 오갈피나무의 플라보노이드 함량은 각각 $55.3 \mathrm{mg} \mathrm{QE} / \mathrm{g}$, $44.0 \mathrm{mgQE} / \mathrm{g}$ 으로 보고된 바 있는데(Kim 등, 2004), 두릅 열 수추출물의 플라보노이드 함량이 이들 식물류보다 높은 수준 이므로 항산화능이 높을 것으로 사료된다.

\section{항산화 활성}

인체 내 항산화의 불균형은 질병을 유발하게 되므로 radical scavenging activity는 항산화 시스템의 중요한 인자로서 질 병 예방에 효과적이다(Reis 등, 2012). 본 연구에서 DPPH와 $\mathrm{ABTS}$ 라디칼 소거활성을 측정한 결과는 Table 2 와 같다.

항산화 활성 측정에 자주 활용되고 있는 $\mathrm{DPPH}$ 는 항산화 물질과 반응하여 anion radical이 소거되면서 보라색에서 노 란색으로 변하는 원리를 이용하여 항산화 활성을 측정한다. 두릅 열수추출물을 $312.5-10,000 \mu \mathrm{g} / \mathrm{mL}$ 의 농도 범위에서 $\mathrm{DPPH}$ 라디칼 소거활성을 측정한 결과, $19.0-73.2 \%$ 의 활성을 나타내었으며 $\mathrm{SC}_{50}$ 값은 $3,274.7 \pm 47.7 \mu \mathrm{g} / \mathrm{mL}$ 로 나타났다. 대 조군으로 사용된 ascorbiac acid의 $\mathrm{SC}_{50}$ 값인 $192.2 \pm 2.1 \mu \mathrm{g} / \mathrm{mL}$ 를 $100 \%$ 로 기준하여 두릅 열수추출물의 relative activity를 환산한 결과, $5.87 \%$ 에 해당하는 수준으로 나타났다.

$\mathrm{ABTS}$ 라디칼 소거활성 측정도 $\mathrm{DPPH}$ 를 이용한 방법과 함께 항산화 활성을 측정하는 데 자주 이용되는 방법이다. $\mathrm{ABTS}$ 가 항산화 물질과 반응하여 cation radical이 소거되면 서 청록색에서 무색으로 변하는 원리를 이용하여 측정한다

Table 2. DPPH and ABTS radical scavenging activity of $A$. elata hot-water extract

\begin{tabular}{ccc}
\hline Sample & $\begin{array}{c}\mathrm{DPPH} \text { radical } \\
\mathrm{SC}_{50}{ }^{1)}(\mu \mathrm{g} / \mathrm{mL})\end{array}$ & $\begin{array}{c}\text { ABTS radical } \\
\mathrm{SC}_{50}(\mu \mathrm{g} / \mathrm{mL})\end{array}$ \\
\hline AHWE $^{2)}$ & $3,274.7 \pm 47.7^{3)}$ & $2,660.1 \pm 50.3$ \\
Ascorbic acid & $192.2 \pm 2.1$ & $101.8 \pm 1.2$ \\
\hline
\end{tabular}

${ }^{1)} \mathrm{SC}_{50}$, concentration required for $50 \%$ scavenging of radicals.

${ }^{2)}$ AHWE, $A$. elata hot-water extract.

${ }^{3)}$ Values represent the mean \pm SD $(\mathrm{n}=3)$. 
(Pellegrini 등 1999). ABTS 라디칼 소거활성을 측정한 결과, $312.5-10,000 \mu \mathrm{g} / \mathrm{mL}$ 의 농도 범위에서 8.2- $63.7 \%$ 의 활성이 측정되었으며, $\mathrm{SC}_{50}$ 값은 $2,660.1 \pm 50.3 \mu \mathrm{g} / \mathrm{mL}$ 로 나타났다. 대 조군으로 사용된 ascorbic acid의 $\mathrm{SC}_{50}$ 값 $(101.8 \pm 1.2 \mu \mathrm{g} / \mathrm{mL})$ 을 기준으로 두릅 열수추출물의 relative activity를 확인한 결 과, $3.83 \%$ 에 해당하는 수준으로 나타났다.

\section{항균활성}

두릅 열수추출물의 H. pylori에 대한 항균활성을 Paper disc diffusion 분석법을 이용하여 측정하였으며, 측정 결과는 Table 3, Fig. 1에 나타내었다. 일정하게 균을 도말한 배지에 두릅 열수추출물을 1-3 mg을 접종한 paper disc를 배치하고 24시간 후 disc 주변에서 clear zone을 확인하였다. 접종된 paper disc에서 1, $2 \mathrm{mg}$ 을 접종한 결과 각각 $1.89 \mathrm{~mm}, 2.14$ $\mathrm{mm}$ 의 clear zone으로 확인되었고, 가장 고농도인 $3 \mathrm{mg}$ 은 $2.85 \mathrm{~mm}$ 의 clear zone으로 확인되었다. 이를 통해 두릅 열수 추출물이 H. pylori에 대해 항균활성 있음이 확인되었으나, 대조군 항생제인 amoxicillin은 $0.1 \mathrm{mg}$ 용량에서 $9.62 \mathrm{~mm}$ 의 clear zone으로 두릅보다 높은 항균활성이 나타났다. 하지만 amoxicillin은 담마진, 소양증, 천식 등 알레르기 반응을 유발

Table 3. Evaluation of antibacterial activity of $\boldsymbol{A}$. elata hot-water extract using paper disc diffusion analysis

\begin{tabular}{ccc}
\hline \multirow{2}{*}{ Sample } & $\begin{array}{c}\text { Concentration } \\
(\mathrm{mg} / \text { disc })\end{array}$ & Diameter of clear zone $(\mathrm{mm})$ \\
\cline { 3 - 3 } & 1 & H. pylori \\
\hline \multirow{2}{*}{ AHWE $^{1)}$} & 2 & 1.89 \\
& 3 & 2.14 \\
\hline Amoxicillin & 0.1 & 2.85 \\
\hline
\end{tabular}

${ }^{1)}$ AHWE, A. elata hot-water extract.
시키는 부작용이 있으며, $\mathrm{pbp} 1 \mathrm{~A}$ 유전자의 돌연변이가 $H$. pylori의 amoxicillin에 대한 내성을 발현시키는 것으로 알려 져 있다(Kim과 Oh, 2017; Lee 등, 2019).

두릅 열수추출물이 H. pylori의 생육을 저해하는 데 필요 한 최소농도를 확인하기 위하여 흡광도를 측정해 생장이 검 출되지 않는 농도를 측정하였다. 또한, 최소의 사멸농도를 확 인하기 위하여 최소저해농도가 나타난 이상의 농도를 배지에 도말하여 최소사멸농도를 확인하였다(Table 4). 두릅 열수추 출물의 $150 \mathrm{mg} / \mathrm{mL}$ 농도에서 최소저해농도를 나타났으며, 최 소사멸농도는 $400 \mathrm{mg} / \mathrm{mL}$ 로 확인되었다. Lee(2014)의 연구에 따르면 소함흥탕 에탄올 추출물과 황련 총 알칼로이드의 $H$. pylori에 대한 최소저해농도는 각각 $250 \mu \mathrm{g} / \mathrm{mL}, 50 \mu \mathrm{g} / \mathrm{mL}$ 이 었다고 보고되었으며, 백지 메탄올 추출물(Choi 등, 2018)의 최소사멸농도는 $250 \mu \mathrm{g} / \mathrm{mL}$ 이었다고 보고되었다.

\section{세포생존율 및 nitric oxide 생성억제능 측정}

H. pylori의 감염에 의하여 위점막이 손상되면 대식세포가 침윤하고 염증세포는 $\mathrm{NO}$ 의 독성에 의하여 위점막이 손상된 다고 보고되었다(Mannick 등, 1996). 또한, 인체 내 과발현된 $\mathrm{NO}$ 는 toxic radical로 작용하여 위점막을 손상시킬 뿐만 아니 라, 파킨슨 병, 뇌막염 및 알츠하이머병과 같은 퇴행성 질환 에 중요한 요인으로 작용한다(Chung 등, 2001; Kawamata

Table 4. Minimum inhibitory concentration (MIC) and minimum bactericidal concentration (MBC) of $A$. elata hot-water extract against $\boldsymbol{H}$. pylori

\begin{tabular}{ccc}
\hline Sample & MIC $(\mathrm{mg} / \mathrm{mL})$ & MBC $(\mathrm{mg} / \mathrm{mL})$ \\
\hline AHWE $^{1)}$ & 150 & 400 \\
Amoxicillin & 0.75 & 1.5 \\
\hline
\end{tabular}

${ }^{1)}$ AHWE, A. elata hot-water extract.
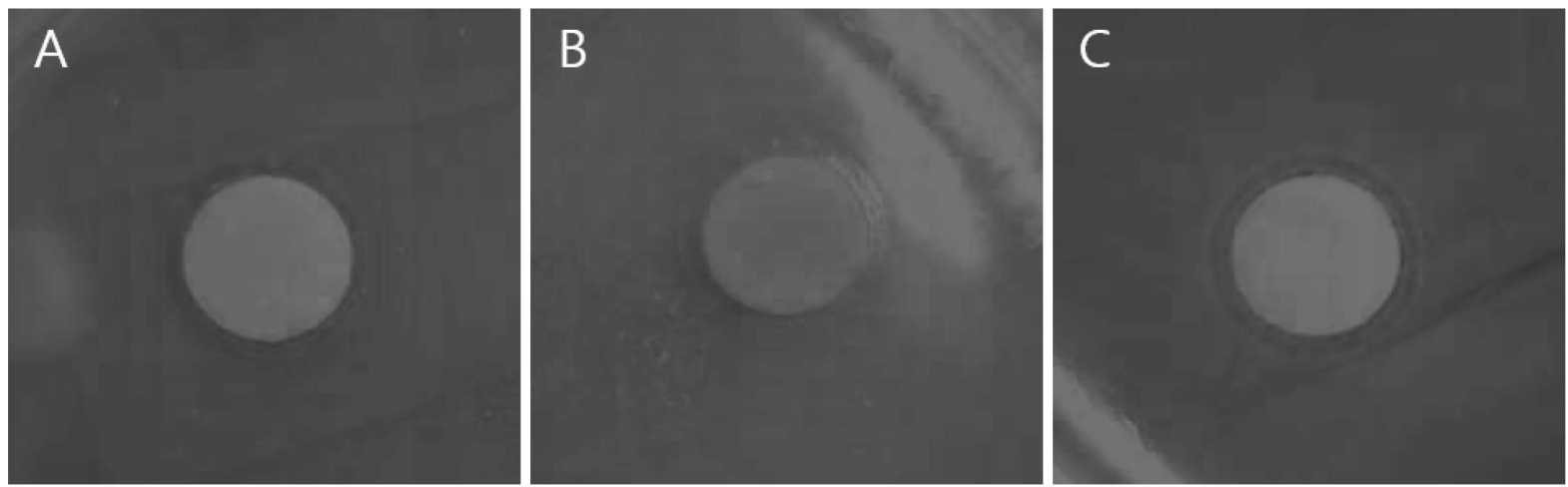

Fig. 1. Antibacterial effect of $A$. elata extract as clear zone of inhibition against $H$. pylori by paper disk diffusion methods. A, $1 \mathrm{mg}$; B, $2 \mathrm{mg}$; C, $3 \mathrm{mg}$. 
등, 2000). 따라서 본 연구에서는 MTT assay를 이용하여 RAW264.7 대식세포에 대한 두릅 열수추출물의 세포 독성을 확인하였다(Fig. 2). 두릅 열수추출물을 농도별( $0,25,50,75$, $100 \mu \mathrm{g} / \mathrm{mL}$ )로 처리한 결과, $100 \mu \mathrm{g} / \mathrm{mL}$ 이하의 농도에서 $99 \%$ 이상의 생존율을 보여 독성을 나타내지 않음을 확인하였 다. 그러므로 독성이 나타내지 않은 $100 \mu \mathrm{g} / \mathrm{mL}$ 이하의 농도 에서 NO 생성 및 염증성 cytokine의 분비량을 측정하였다. LPS로 염증이 유도된 RAW264.7 세포에 두릅 열수추출물을 $25,50,75,100 \mu \mathrm{g} / \mathrm{mL}$ 농도별로 처리하여 $\mathrm{NO}$ 생성을 측정 한 결과를 Fig. 3에 나타내었다. LPS 처리군에 대비 두릅 열 수추출물 $25,50,75,100 \mu \mathrm{g} / \mathrm{mL}$ 의 농도에서 각각 $76.6 \pm 0.6$, $72.5 \pm 0.5,66.4 \pm 3.1,56.3 \pm 2.6 \%$ 로 농도 의존적으로 $\mathrm{NO}$ 생성 량이 감소됨을 확인하였다. 이를 통해 두릅 열수추출물에서 $\mathrm{NO}$ 생성의 억제가 확인됨에 따라 두릅은 다양한 염증인자들 을 억제할 수 있을 것으로 사료된다.

\section{염증성 cytokine 분비량 측정}

Cytokine은 대식세포와 같은 면역세포가 분비하는 단백질 로서 면역세포의 증식, 활성 및 분화 조절을 통해 염증을 활 성화시키는 매개하는 인자이며, 염증반응을 조절하는 TNF$\alpha, \mathrm{IL}-1 \beta, \mathrm{IL}-6$ 은 대표적인 pro-inflammatory cytokine으로 알 려져 있다(Namkoong 등, 2015). LPS로 염증이 유도된 RAW264.7 세포에 두릅 열수추출물을 농도별로 처리한 후, 생성되는 TNF- $\alpha, \mathrm{IL}-1 \beta, \mathrm{IL}-6$ 의 생성량을 측정함으로써 두릅 열수추출물에 의한 염증성 cytokine의 생성 억제 효과를 검 토하였다(Fig. 4). LPS로 인하여 RAW264.7 세포에서 TNF-

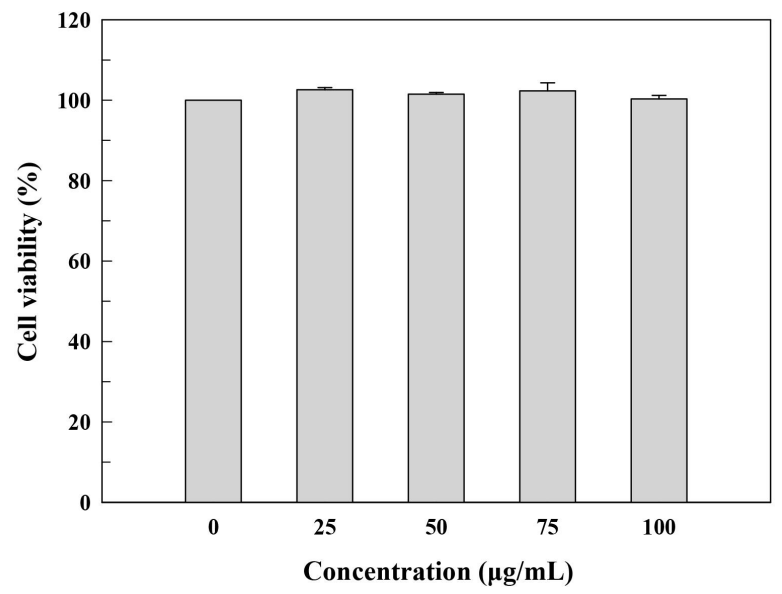

Fig. 2. Cell viability according to treatment of $A$. elata extract on RAW264.7 cell.

Values represent the mean $\pm \mathrm{SD}(\mathrm{n}=3)$. Means with different superscript in the same column are significantly different $(p<0.05)$ by Duncan's multiple range test $\mathrm{p}<0.01,{ }^{*} \mathrm{p}<0.005,{ }^{*} \mathrm{p}<0.001$.

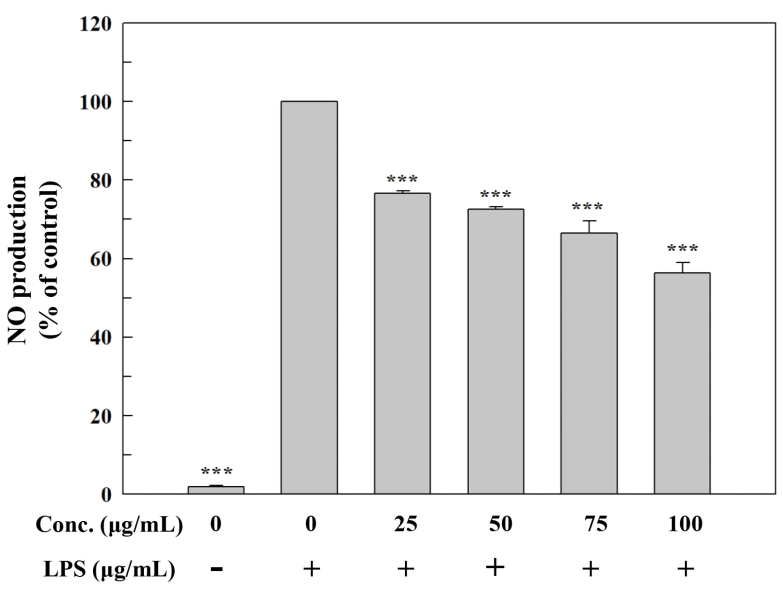

Fig. 3. Inhibitory effects of nitric oxide production according to treatment of $A$. elata extract on LPS-induced RAW264.7 cell.

Values represent the mean $\pm \mathrm{SD}(\mathrm{n}=3)$. Means with different superscript in the same column are significantly different $(\mathrm{p}<0.05)$ by Duncan's multiple range test ${ }^{*} \mathrm{p}<0.01,{ }^{* *} \mathrm{p}<0.005,{ }^{* * *} \mathrm{p}<0.001$.

$\alpha, \mathrm{IL}-1 \beta, \mathrm{IL}-6$ 생성이 증가하였으나, 두릅 열수추출물(25, $50,75,100 \mu \mathrm{g} / \mathrm{mL}$ ) 처리군에서는 농도 의존적으로 억제되었 다. 두릅 열수추출물의 $100 \mu \mathrm{g} / \mathrm{mL}$ 농도에서 TNF- $\alpha, \mathrm{IL}-6$ 의 생성량을 각각 $31.9,39.2 \%$ 로 억제됨을 확인하였고 특히, IL-1 1 의 생성량을 $61.1 \%$ 로 억제시킴으로써 cytokine 중 가 장 높게 억제되었다. 따라서 두릅 열수추출물은 염증성 cytokine의 생성 억제를 통해 항염증 효과를 나타냄을 확인 하였다.

\section{요 약}

두릅(A. elata)은 두릅나뭇과(Araliaceae)에 속하는 식물로 식용과 약용으로 사용되고 있으며, 사포닌, 올리에놀산, 트 라이터펜 등의 성분을 함유하고 있어 항산화, 당뇨, 항염증 등에 효과가 있다. 두릅은 살모넬라와 대장균의 생장억제에 대한 효과가 보고되어 있지만, H. pylori에 관한 연구는 거의 연구된 된 바가 없다. 본 연구는 순창군에서 재배한 두릅을 활용하여 $80^{\circ} \mathrm{C}$ 의 water 조건에서 5 시간 동안 추출하였고, 얻 어진 추출물의 total polyphenol 및 flavonoid 함량, 항산화 활성, 항균 및 항염 효과를 조사하였다. 두릅 열수추출물의 total polyphenol 및 flavonoid 함량은 각각 $186.8 \pm 2.7 \mathrm{mg}$ $\mathrm{GAE} / \mathrm{g}, 81.9 \pm 1.5 \mathrm{mg} \mathrm{QE} / \mathrm{g}$ 으로 확인되었다. 두릅 열수추출 물의 $\mathrm{DPPH}$ 라디칼 소거활성 $\mathrm{SC}_{50}$ 값은 $3,274.7 \pm 47.7 \mu \mathrm{g} / \mathrm{mL}$ 로 대조군으로 사용한 ascorbic acid $\mathrm{SC}_{50}$ 값 $(192.2 \pm 2.1 \mu \mathrm{g} / \mathrm{mL})$ 의 $5.87 \%$ 에 해당하며, $\mathrm{ABTS}$ 라디칼 소거활성 $\mathrm{SC}_{50}$ 값은 $2,660.1 \pm 50.3 \mu \mathrm{g} / \mathrm{mL}$ 로 ascorbic acid $\mathrm{SC}_{50}$ 값 $(101.8 \pm 1.2 \mu \mathrm{g} / \mathrm{mL})$ 의 $3.83 \%$ 에 해당하는 수준으로 확인되었다. Paper disc 

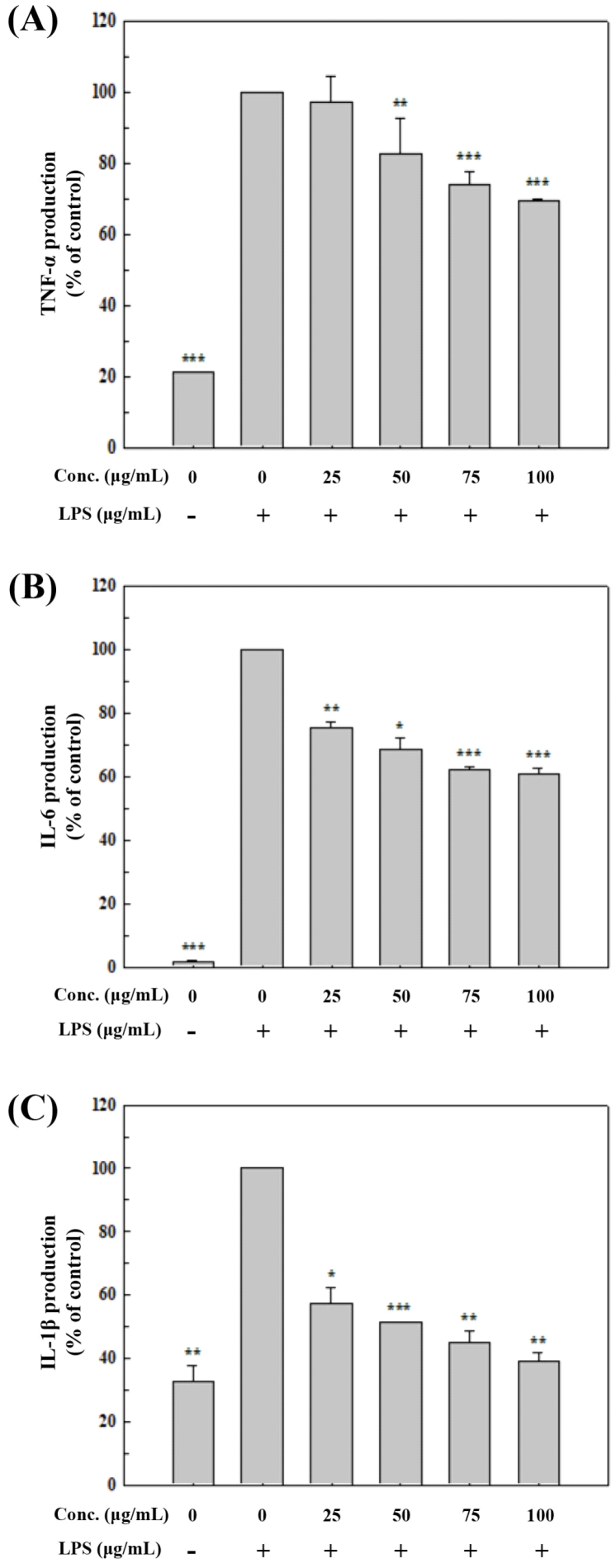

Fig. 4. Inhibitory effects of pro-inflammatory cytokines (TNF- $\alpha$, IL-1 $\beta$, IL-6) production according to treatment of $A$. elata extract on LPS-induced RAW264.7 cell.

A, TNF- $\alpha$; B, IL-1 $\beta$; C, IL-6 production.

Values represent the mean \pm SD $(n=3)$. Means with different superscript in the same column are significantly different $(\mathrm{p}<0.05)$ by Duncan's multiple range test ${ }^{*} \mathrm{p}<0.01,{ }^{* *} \mathrm{p}<0.005,{ }^{* * *} \mathrm{p}<0.001$. diffusion 분석법으로 H. pylori에 대한 항균활성을 측정한 결과, $1,2,3 \mathrm{mg}$ 용량에서 각각 $1.89,2.14,2.85 \mathrm{~mm}$ 의 clear zone이 확인되었다. 두릅 열수추출물의 H. pylori에 대한 최 소저해농도 및 최소사멸농도를 확인한 결과, 각각 150,400 $\mathrm{mg} / \mathrm{mL}$ 로 나타내었다. RAW264.7 세포에 대한 세포생존율 은 $100 \mu \mathrm{g} / \mathrm{mL}$ 이내의 농도에서 세포독성이 나타나지 않았 고, $\mathrm{NO}$ 생성을 농도 의존적으로 감소시켰다. 또한, 염증성 cytokine인 TNF- $\alpha$, IL-1 $\beta$ 및 IL-6의 생성량을 농도 의존적으 로 억제시켰다. 따라서 두릅 열수추출물의 천연 항균 및 항 염증제로의 활용 가능성을 제시하는 결과로 사료된다.

\section{Conflict of interests}

The authors declare no potential conflict of interest.

\section{ORCID}

Se-Won Lee https://orcid.org/0000-0002-9739-7336

Jeong Ho Lee https://orcid.org/0000-0002-1052-1497

\section{References}

Ahn JY. Effectiveness of Helicobacter pylori eradication before endoscopic resection. The Korean J Helicobacter Up Gastrointest Res, 19, 215-219 (2019)

Blois MS. Antioxidant determinations by the use of a stable free radical. Nature, 181, 1199-1200 (1958)

Carmichael J, DeGraff WG, Gazdar AF, Minna JD, Mitchell JB. Evaluation of a tetrazolium-based semiautomated colorimetric assay: Assessment of chemosensitivity testing. Cancer Res, 47, 936-942 (1987)

Cha JY, Ahn HY, Eom KE, Park BK, Jun BS, Cho YS. Antioxidative activity of Aralia elata shoot and leaf extracts. J Life Sci, 19, 652-658 (2009)

Chae IG, Yu MH, Kim HI, Lee IS. Anti-inflammatory and anti-oxidative activity of methanol extract from Terminalia chebula Retz., Lavandula spica L., and Dalbergia odorifera T. in RAW 264.7 cells. J Life Sci, 21, 561-567 (2011)

Choi JY, Kim HM, Mok SY, Choi K, Ku JJ, Park KW, Cho EJ, Lee SH. Antibacterial activity and protective role against gastric cancer by Sedum sarmentosum. J Appl Biol Chem, 55, 157-161 (2012)

Choi MK, Yim DS, Choi SS. Anti-bacterial and antiinflammatory effects of Angelica dahurica extracts in 
Helicobacter pylori-infected human gastric epithelial AGS cells. Kor J Phamacogn, 49, 255-261 (2018)

Chung HJ. Comparison of total polyphenols, total flavonoids, and biological activities of black chokeberry and blueberry cultivated in Korea. J Korean Soc Food Sci Nutr, 43, 1349-1356 (2014)

Chung HT, Pae HO, Choi BM, Billiar TR, Kim YM. Nitric oxide as a bioregulator of apoptosis. Biochem Biophys Res Commun, 282, 1075-1079 (2001)

De Francesco V, Zullo A, Hassan C, Giorgio F, Rosania R, Ierardi E. Mechanisms of Helicobacter pylori antibiotic resistance: An updated appraisal. World J Gastrointest Pathophysiol, 2, 35-41 (2011)

Green LC, Wagner DA, Glogowski J, Skipper PL, Wishnok JS, Tannenbaum SR. Analysis of nitrate, nitrite, and $\left[{ }^{15} \mathrm{~N}\right]$ nitrate in biological fluids. Anal Biochem, 126, 131-138 (1982)

Healthcare Bigdata Hub. 100 Disease Statistics in Living. Health Insurance Review and Assessment Service. http:// opendata.hira.or.kr/op/opc/olap3thDsInfo.do. (accessed March 2018)

Hofseth LJ, Ying L. Identifying and defusing weapons of mass inflammation in carcinogenesis. Biochim Biophys Acta, 1765, 74-84 (2006)

Jin JY, Park EH, Jeon YA, Lee YJ. Antihypertensive effect of ethanol extracts of Aralia elata in spontaneously hypertensive rats. Korean J Vet Res, 57, 181-187 (2017)

Kawamata H, Ochiai H, Mantani N, Terasawa K. Enhanced expression of inducible nitric oxide synthase by Juzentaiho-to in LPS-activated Raw264.7 cells, a murine macrophage cell line. Am J Chin Med, 28, 217-226 (2000)

Kim EJ, Choi JY, Yu MR, Kim MY, Lee SH, Lee BH. Total polyphenols, total flavonoid contents, and antioxidant activity of Korean natural and medicinal plants. Korean J Food Sci Technol, 44, 337-342 (2012)

Kim EY, Baik IH, Kim JH, Kim SR, Rhyu MR. Screening of the antioxidant activity of some medicinal plants. Korean J Food Sci Technol, 36, 333-338 (2004)

Kim HS, Oh JK. Development of antibiotic prescription guidelines for antibiotic prescription quality management. J Korean Academy Dental Administration, 5, 45-54 (2017)

Kim HY, Woo SO, Kim SG, Bang KW, Choi HM, Moon
HJ, Han SM. Anti-inflammatory activities of drone pupae (Apis mellifera L.) in macrophages. J Apiculture, 34, 255- 259 (2019)

Kim MJ, Cho SY, Lee MK, Shin KH. Effects of Aralia elata water extracts on activities of hepatic oxygen free radical generating and scavenging enzymes in streptozotocin-induced diabetic rats. J Korean Soc Food Sci Nutr, 33, 653-658 (2004)

Kim SK, Woo SO, Han SM, Kim SG, Bang KW, Jang HR, Moon HJ, Kim HJ. Anti-inflammatory effects of Korean propolis extracts on Raw264.7 macrophage cells. J Apiculture, 33, 187-194 (2018)

Kim YJ. Evaluation of antioxidant activity and thermal stability of plant polyphenols. Biomaterials Res, 13, 3036 (2009)

Kwon BS, Park SK, Kim JM, Kang JY, Park SH, Kang JE, Lee CJ, Park SB, Yoo SK, Lee U, Heo HJ. Antioxidant capacity and hepatoprotective effect of ethyl acetate fraction from shoot of Aralia elata on alcohol-induced cytotoxicity. Korean J Food Sci Technol, 50, 216-224 (2018)

Lee BW, Choi MS, Yim DS, Choi SS. In vitro antiHelicobacter pylori activity of ethanol extract of Sohamhyoongtang and coptidis rhizoma total alkaloids. Kor J Pharmacogn, 45, 168-173 (2014)

Lee DJ, Jeong JC. peroxynitrite scavenging activity of Samjunghwan. J Int Korean Med, 27, 178-187 (2006)

Lee JH, Kim JS, Park JS. Antibacterial effect of medicinal plants against Helicobacter pylori. J Digital Convertgence, 17, 447-451 (2019)

Lee MJ, Lee SJ, Choi HR, Lee JH, Kwon JW, Chae KS, Jeong JT, Lee TB. Improvement of cholesterol and blood pressure in fruit, leaf and stem extracts from black raspberry in vitro. Korean J Medicinal Crop Sci, 22, 177-187 (2014)

Lee SH, Jin KS, Kim BW, Kwon HJ. The anti-oxidative and anti-inflammatory activities of Malus melliana ethanol extract. J Life Sci, 27, 783-789 (2017)

Lee YM, Bae JH, Jung HY, Kim JH, Park DS. Antioxidant activity in water and methanol extracts from Korean edible wild plants. J Korean Soc Food Sci Nutr, 40, 29-36 (2011)

Ma SJ, Ko BS, Park KH. Isolation of 3,4-dihydroxybenzoic acid with antimicrobial activity from bark of Aralia 
elata. Korean J Food Sci Technol, 27, 807-812 (1995) Mannick EE, Bravo LE, Zarama G, Realpe JL, Zhang XJ, Ruiz B, Fontham ETH, Mera R, Miller MJS, Correa P. Inducible nitric oxide synthase, nitrotyrosine, and apoptosis in Helicobacter pylori gastritis: Effect of antibiotics and antioxidants. Cancer Res, 56, 3238-3243 (1996)

Min JY, Park YK. Effect of dipsaci radix water extract on LPS-induced inflammatory response in RAW264.7 mouse macrophages. Kor J Herbology, 24, 189-195 (2009)

Moon HK, OH KE, Son SH. Factors influencing somatic embryo induction and plant regeneration in Aralia elata Seem. Korean J Plant Tissue Culture, 26, 275-280 (1999)

Moreno MIN, Isla MI, Sampietro AR, Vattuone MA. Comparison of the free radical-scavenging activity of propolis from several regions of Argentina. J Ethopharmacol, 71, 109-114 (2000)

Namkoong S, Jang SA, Sohn EH, Bak JP, Sohn ES, Koo HJ, Yoon WJ, Kwon JE, Jeong YJ, Meng X, Han HS, Kang SC. Comparative study of Lisea japonica leaf and fruit extract on the anti-inflammatory effects. Korean J Plant Res, 28, 145-152 (2015)

Oh MH, Kim MJ, Shin MR, Park HJ, Seo BI, Roh SS. Gastroprotective activity of Curcumae longae rhizoma against gastric ulcer in mice. Kor $\mathrm{J}$ Herbology, 35, 17-24 (2020)

Park YS, Kim YH. The effect of medicinal herb extract on antimicrobial activity against Helicobacter pylori and antioxidant activity. J East Asiam Soc Diet Life, 16, 199-206 (2006)
Radi R, Beckman JS, Bush KM, Freeman BA. Peroxynitrite oxidation of sulfhydryls: The cytotoxic potential of superoxide and nitric oxide. J Biol Chem, 266, 4244-4250 (1991)

Re R, Pellegrini N, Proteggente A, Pannala A, Yang M, Rice-Evans C. Antioxidant activity applying an improved ABTS radical cation decolorization assay. Free Radic Biol Med, 26, 1231-1237 (1999)

Reis FS, Martins A, Barros L, Ferreira ICFR. Antioxidant properties and phenolic profile of the most widely appreciated cultivated mushrooms: A comparative study between in vivo and in vitro samples. Food Chem Toxicol, 50, 1201-1207 (2012)

Singleton VL, Rossi JA. Colorimetry of total phenolics with phosphomolybdic-phosphotungstic acid reagents. Am J Enol Viticult, 16, 144-158 (1965)

Takarada K, Kimizuka R, Takahashi N, Honma K, Okuda $\mathrm{K}$, Kato T. A comparison of the antibacterial efficacies of essential oils against oral pathogens. Oral Microbiol Immunol, 19, 61-64 (2004)

Van den Berg R, Haenen GRMM, van den Berg H, Bast A. Applicability of an improved trolox equivalent antioxidant capacity (TEAC) assay for evaluation of antioxidant capacity measurements of mixtures. Food Chem, 66, 511-517 (1999)

Yoon SJ, Kim JS, Jo BS, Kim JH, Lee SH, Ahn BJ, Cho YJ. Isolation and identification of antimicrobial compounds against Helicobacter pylori from rosemary (Rosmarinus officinalis L.) extracts. J Appl Biol Chem, 54, 159-165 (2011) 